\title{
Karakteristik Morfologi dan Anatomi, serta Kandungan Klorofil Lima Kultivar Tanaman Penyerap Polusi Udara Sansevieria trifasciata.
}

\author{
RITA MEGIA*, RATNASARI, HADISUNARSO \\ ${ }^{1}$ Departemen Biologi, Fakultas Matematika dan Ilmu Pengetahuan Alam, \\ Institut Pertanian Bogor, Bogor 16680, Indonesia
}

Diterima 11 Februari 2015/Disetujui 26 Maret 2015

\begin{abstract}
Sansevieria trifasciata is an unique houseplant that can provide clean air to occupied room because it can absorb harmful substances from the air. This research aim to compare morphological, and anatomical characters and chlorophyll content of five cultivars of this plant. Morphological characters of all $S$. trifasciata cultivars observed varied in pattern, colour, and size of the leaf. Stomata can be found on both leaf surfaces; abaxial side have higher stomatal density than adaxial side. Distribution of single stomata was presented in all cultivars, while clustered stomata were also found in cv. Moonsine. Among all cultivars, stomatal density and stomatal index were found the highest in cv. Moonsine. The highest chlorophyll content, the longest leaf, widthest leaf and the thinnest leaf were found in cv. African Dawn. Potentially, S. trifasciata cv. African Dawn and $S$. trifasciata cv. Moonsine could absorb air pollution better than the other cultivars.
\end{abstract}

Key word: Sansevieria trifasciata, morphology, anatomy, chlorophyll content, air pollution.

\section{PENDAHULUAN}

Sansevieria trifasciata atau lidah mertua merupakan tanaman hias yang sering dijumpai di pinggir jalan, di taman, dan di perkarangan atau ditanam dalam pot sebagai penghias ruangan. Tanaman ini diklasifikasikan dalam Famili Asparagaceae (Backer dan Bakhuizen 1963). Sebagian besar Sansevieria sp. berasal dari benua Afrika, dan sebagian yang lainnya berasal dari Asia. Jumlah kultivar tanaman ini di dunia lebih dari 600, sedang di Indonesia diketahui ada sekitar 100 kultivar (Stover 1983). Kultivarkultivar ini memiliki daun yang bervariasi dalam bentuk, ukuran, warna, dan teksturnya.

Selain bentuknya unik, lidah mertua mampu memberikan udara bersih bagi ruangan yang ditempatinya karena tanaman ini dapat menyerap zat berbahaya di udara. Penelitian Lembaga Badan Antariksa Nasional Amerika Serikat (NASA) menunjukkan bahwa lidah mertua mampu menyerap lebih dari 107 unsur polutan yang ada dan berbahaya di udara. Sansevieria sp. mampu menyerap zat polutan karena memiliki bahan aktif pregnane glikosid yang berfungsi untuk mereduksi polutan menjadi asam organik, gula, dan asam amino sehingga unsur polutan tersebut menjadi tidak berbahaya lagi bagi manusia. Riset yang dilakukan oleh Wolverton

*Penulis korespondensi : 08128002500 ,

E-mail: ritamegia@cbn.net.id
Environmental Service juga menunjukkan bahwa satu helai lidah mertua dalam satu jam mampu menyerap $0.938 \mathrm{mg}$ formaldehid.

Kemampuan tanaman dalam menyerap dan mengakumulasi polutan dipengaruhi oleh karakteristik morfologi daun, seperti: ukuran, bentuk, dan tekstur daun (Starkman 1969). Selain itu proses penyerapan polusi udara terjadi pada daun yang mengandung banyak stomata (Gardner et al. 1991). Tanaman yang mempunyai stomata banyak dan tumbuh cepat merupakan tanaman yang baik digunakan dalam penyerapan polutan (Fakuara 1996). Mekanisme masuknya polutan ke dalam daun umumnya terjadi pada siang hari saat daun melepas uap air dan mengambil $\mathrm{CO}_{2}$ serta gas lainnya termasuk polutan yang ada di daun melalui stomata. Banyaknya stomata dalam satu satuan luas daun menentukan masuknya gas pencemar yang terserap oleh tanaman (Smith 1981). Kadar klorofil pada daun tanaman dapat digunakan sebagai indikator penyerap polusi udara (Karliansyah 1999). Kemampuan tanaman dalam menyerap polusi udara bersamaan saat penyerapan $\mathrm{CO}_{2}$ yang akan digunakan dalam proses fotosintesis.

Melihat kemampuan $S$. trifasciata dalam penyerapan polusi udara, maka dilakukan penelitian untuk membandingkan karakter morfolzzogi, anatomi, dan kandungan klorofil beberapa kultivar tanaman ini. 


\section{BAHAN DAN METODE}

Bahan. Bahan tanaman yang digunakan yaitu lima kultivar $S$. trifasciata yang terdiri atas: cv. Metalica, cv. Moonsine, cv. African Dawn, dan cv. Bantel's, serta satu kultivar yang belum diketahui namanya sehingga diberi kode cv. NN. Bahan kimia yang digunakan adalah alkohol 70\%, HNO3, kloroks, pewarna safranin, gliserin $30 \%$, dan aseton $80 \%$.

Metode. Ke lima kultivar S. trifasciata ditanam dalam polybag di rumah kaca milik Departemen Biologi FMIPA di kampus Dramaga, IPB sebanyak 3 kali ulangan. Media yang digunakan berisi tanah, pupuk kandang, dan sekam dengan perbandingan $2: 1: 1$.

\section{Pengamatan Morfologi}

Pengamatan morfologi dilakukan pada setiap kultivar dengan 3 kali ulangan (tanaman). Panjang dan lebar daun tanaman dewasa diukur dengan menggunakan meteran/ penggaris.

2. Pembuatan Preparat Anatomi meliputi:

a) Sediaan Sayatan Paradermal menggunakan metode whole mount (Sass 1951).

Sediaan paradermal dibuat dari tiga posisi, yaitu pangkal, tengah, dan ujung daun yang telah difiksasi dalam alkohol $70 \%$. Selanjutnya daun dicuci dengan akuades dan direndam dalam asam nitrat $70 \%$ selama 20 menit. Kemudian daun dibilas lagi dengan akuades, dilanjutkan dengan penyajatan daun menggunakan silet sehingga diperoleh epidermis adaksial dan abaksial. Hasil sayatan dicuci dengan kloroks 1\% (dari produk "Bayclin"), kemudian dibilas kembali dengan akuades dan diwarnai dengan safranin $1 \%$, lalu diamati dalam media gliserin $30 \%$.

b) Sediaan Sayatan Transversal.

Daun berukuran $0.5 \times 1 \mathrm{~cm}$ diambil pada bagian ujung, lalu difiksasi dengan alkohol 70\%. Selanjutnya potongan daun dibilas dengan akuades lalu disayat secara transversal dengan mikrotom beku setebal $20 \mu \mathrm{m}$. Hasil sayatan diwarnai dengan safranin 1\% lalu diamati dalam media gliserin $30 \%$.

Pengamatan Anatomi daun dilakukan pada ke 5 kultivar dwengan 3 ulangan tanaman. Penentuan kerapatan stomata KS [jumlah stomata/luas bidang pandang $\left(\mathrm{mm}^{2}\right)$ ] dan nilai indeks stomata IS [jumlah stomata/(jumlah stomata + jumlah epidermis)] x 100 mengikuti rumus Wilmer (1983).

Tabel 1. Ukuran panjang dan lebar daun ke lima kultivar S. trifasciata

\begin{tabular}{llrrrr}
\hline \multirow{2}{*}{ No } & \multicolumn{1}{c}{ Kultivar } & \multicolumn{2}{c}{ Ukuran daun $(\mathrm{cm})$} & \multirow{2}{*}{ Bentuk daun } \\
\cline { 3 - 5 } & & Panjang(P) & Lebar $(\mathrm{L})$ & $\mathrm{P} / \mathrm{L}$ & Pedang \\
\hline 1 & cv. Mewtalica & $52.3 \pm 0.2$ & $4.1 \pm 0.5$ & 2.7 & Lanset \\
2 & cv. Moonsine & $33.6 \pm 0.2$ & $8.6 \pm 0.5$ & 3.9 & Lanset \\
3 & cv. African Dawn & $64.2 \pm 0.9$ & $12.8 \pm 0.3$ & 5.0 & Lanset \\
4 & cv. NN & $41.2 \pm 0.7$ & $8.2 \pm 0.5$ & 5.0 & Pedang \\
5 & cv. Bantel's Sensation & $63.3 \pm 1.0$ & $1.6 \pm 0.7$ & 39.5 & \\
\hline
\end{tabular}

3. Analisis Kandungan Klorofil menggunakan metode Arnon (1949).

Satu gram potongan daun bagian ujung ditumbuk dalam mortar sampai halus. Hancuran daun ditambah aseton $80 \%$, kemudian disaring dengan kertas saring ke dalam labu ukur dan ditambahkan aseton $80 \%$ hingga $50 \mathrm{ml}$. Sebanyak $5 \mathrm{ml}$ ekstrak klorofil diambil dengan mikropipet dan dimasukkan kedalam labu ukur lalu ditambahkan aseton $80 \%$ hingga $25 \mathrm{ml}$. Ekstrak klorofil diukur absorbansinya dengan spektrofotometer pada panjang gelombang $663 \mathrm{~nm}$ dan $645 \mathrm{~nm}$. Pengukuran diulang dengan menggunakan tiga sampel tanaman untuk setiap kultivar.

Analisis Data. Analisis sidik ragam data kandungan Product and Service Solution (SPSS) 17.0 dan uji lanjut Duncan pada selang kepercayaan $1 \%$.

\section{HASIL}

Karakter Morfologi. Ukuran panjang dan lebar daun ke lima kultivar disajikan pada Tabel 1. Berdasarkan pengamatan ke lima kultivar $S$. trifasciata memiliki bentuk daun seperti pedang atau lanset, sedang warna daun berbeda-beda antar kultivar (Gambar 1). S. trifasciata cv. Metalica (Gambar 1a) memiliki daun yang tebal dengan bentuk pedang, ujung daun meruncing, berwarna perak dengan garis-garis vertikal berwarna hijau, jumlah helaian daun 5-8. S. trifasciata cv. Moonsine (Gambar 1b) memiliki daun yang tebal dengan bentuk lanset, ujung daun meruncing, berwarna silver hingga hijau tanpa corak dengan bagian tepi daun berwarna hijau gelap, dengan 4-7 helai daun. S. trifasciata cv. African Dawn (Gambar 1c) memiliki daun yang tebal dengan bentuk lanset, ujung daun meruncing, permukaan daun licin, berwarna hijau dengan corak berbintik-bintik putih hingga hijau dengan garis-garis hijau gelap dan bagian tepi daun berwarna semburat merah muda jumlah helaian daun 4-6. S. trifasciata cv. NN (Gambar 1d) memiliki daun yang tebal dengan bentuk lanset, ujung daun meruncing, berwarna hijau dengan garis-garis horizontal berwarna hijau gelap, jumlah helaian daun 4-6. S. trifasciata cv. Bantel's Sensation (Gambar 1e) memiliki daun yang tebal dengan bentuk pedang, ujung daun meruncing, berwarna hijau gelap dengan garis-garis vertikal berwarna putih dengan 3-5 helai daun. klorofil dikerjakan menggunakan software Statistic 
Karakter Anatomi. Sel penjaga stomata kelima kultivar $S$. trifasciata yang diamati memiliki bentuk ginjal. Pada semua kultivar stomata tersebar tunggal, namun pada kultivar $S$. trifasciata cv. Moonsine, selain stomata tunggal juga dijumpai stomata yang berkelompok (Gambar 2). Epidermis kelima kultivar S. trifasciata berbentuk poligonal dengan 4 hingga 6 sisi yang berdinding tipis. Struktur epidermis daun bagian adaksial dan abaksial ke lima kultivar disajikan pada Gambar 3 dan Gambar 4, Kultivar Moonsine memiliki sel epidermis yang lebih rapat dibandingkan kultivar lainnya.

Kerapatan Stomata (KS) dan Indeks Stomata (IS) ke lima kultivar $S$. trifasciata ditunjukkan pada Tabel 2, sedang ukuran stomata pada Tabel 3. KS, IS dan ukuran stomata yang lebih tinggi dijumpai pada bagian abaksial dibandingkan bagian adaksial daun. Berdasarkan posisi daun, umumnya bagian tengah daun memiliki nilai ukuran, KS dan IS yang lebih tinggi dibandingkan bagian pangkal dan ujung daun.

Gambar 5 menunjukkan sayatan transversal daun ke lima kultivar S. trifasciata menggunakan mikrotom

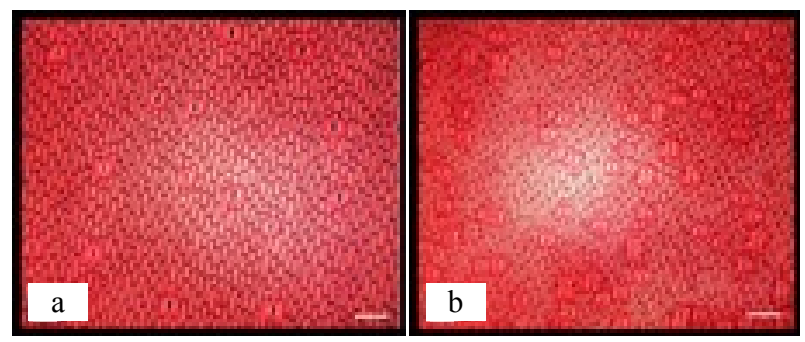

Gambar 2. Sebaran stomata : (a). tunggal dan (b). berkelompok pada S. trifasciata cv. Moonsine. Garis skala: 100 $\mu \mathrm{m}$

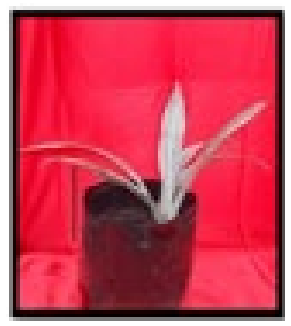

(a)

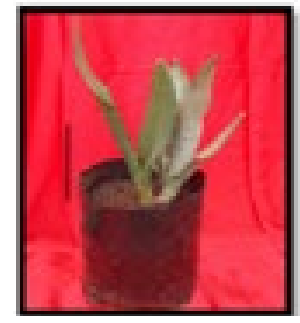

(b)

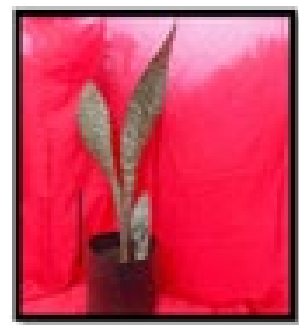

(c)

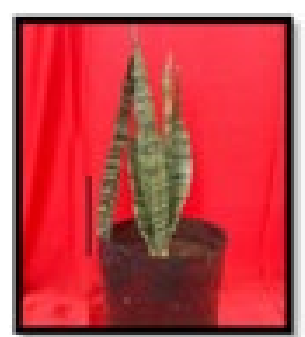

(d)

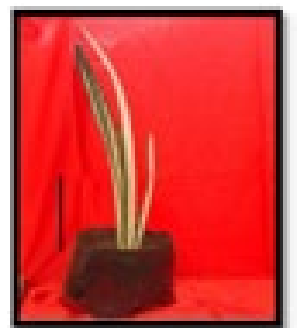

(e)

Gambar 1. Morfologi ke lima kultivar Sansevieria trifasciata: (a). cv. Metalica, (b). cv. Moonsine, (c). cv. African Dawn, (d) cv. NN, dan (e). cv. Bantel's Sensation. Garis skala: $30 \mathrm{~cm}$
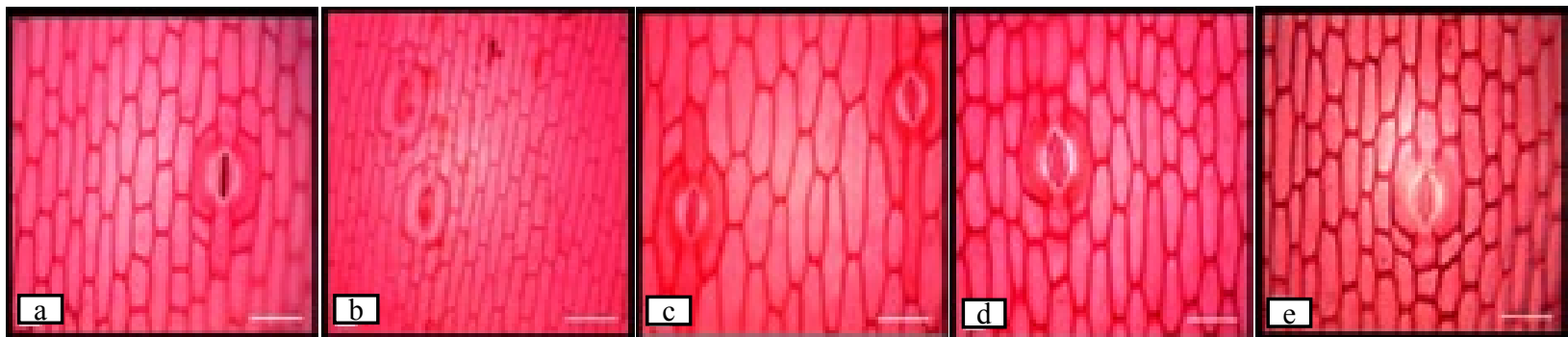

Gambar 3. Struktur epidermis adaksial daun ke lima kultivar S. trifasciata : (a). cv. Metalica, (b). cv. Moonsine, (c). cv. African Dawn, (d) cv. NN, dan (e). cv. Bantel's Sensation. Garis skala: $50 \mu \mathrm{m}$

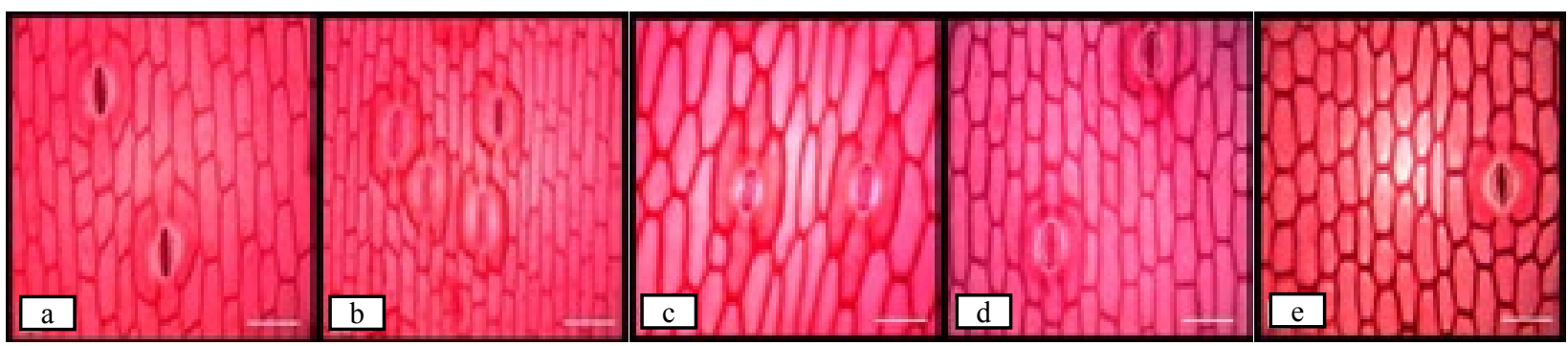

Gambar 4. Struktur epidermis abaksial daun ke lima kultivar S. trifasciata : (a). cv. Metalica, (b). cv. Moonsine, (c). cv. African Dawn, (d) cv. NN, dan (e). cv. Bantel's Sensation. Garis skala: $50 \mu \mathrm{m}$ 
Tabel 2. Kerapatan stomata dan Indeks stomata sayatan paradermal ke lima kultivar S. trifasciata

\begin{tabular}{|c|c|c|c|c|c|c|}
\hline \multirow[t]{2}{*}{ No } & \multirow[t]{2}{*}{ Kultivar } & \multirow[t]{2}{*}{ Posisi } & \multicolumn{2}{|c|}{ Kerapatan stomata ( $\sum$ stomata $\left./ \mathrm{mm} 2\right)$} & \multicolumn{2}{|c|}{ Indeks stomata* } \\
\hline & & & Adaksial & Abaksial & Adaksial & Abaksial \\
\hline \multirow[t]{4}{*}{1} & cv. Metalica & Pangkal & 9.7 & 11.2 & 2.1 & 1.7 \\
\hline & & Tengah & 9.5 & 15.0 & 2.0 & 2.6 \\
\hline & & Ujung & 13.6 & 14.4 & 2.3 & 2.6 \\
\hline & & Rataan & $10.9 \pm 2.3$ & $13.5 \pm 2.0$ & $2.1 \pm 0.2$ & $2.3 \pm 0.5$ \\
\hline \multirow[t]{4}{*}{2} & cv. Moonsine & Pangkal & 40.6 & 44.6 & 5.5 & 8.3 \\
\hline & & Tengah & 39.5 & 50.3 & 10.3 & 10.2 \\
\hline & & Ujung & 42.7 & 49.3 & 8.5 & 8.6 \\
\hline & & Rataan & $40.9 \pm 1.6$ & $48.1 \pm 3.0$ & $8.1 \pm 2.4$ & $9.0 \pm 1.0$ \\
\hline \multirow[t]{4}{*}{3} & cv. African Dawn & Pangkal & 10.1 & 13.9 & 3.5 & 4.6 \\
\hline & & Tengah & 10.2 & 14.0 & 3.9 & 4.7 \\
\hline & & Ujung & 12.9 & 15.6 & 3.7 & 4.9 \\
\hline & & Rataan & $11.2 \pm 1.6$ & $14.5 \pm 0.9$ & $3.7 \pm 0.2$ & $4.7 \pm 0.2$ \\
\hline \multirow[t]{4}{*}{4} & cv. NN & Pangkal & 12.7 & 13.4 & 3.1 & 3.6 \\
\hline & & Tengah & 12.6 & 15.8 & 3.0 & 4.0 \\
\hline & & Ujung & 14.1 & 16.9 & 2.7 & 3.9 \\
\hline & & Rataan & $13.1 \pm 0.8$ & $15.4 \pm 1.8$ & $2.0 \pm 0.2$ & $3.8 \pm 0.2$ \\
\hline \multirow[t]{4}{*}{5} & cv. Bantel's Sensation & Pangkal & 3.4 & 4.1 & 1.2 & 1.6 \\
\hline & & Tengah & 4.7 & 5.5 & 2.1 & 2.2 \\
\hline & & Ujung & 4.3 & 6.0 & 1.6 & 2.1 \\
\hline & & Rataan & $4.1 \pm 0.7$ & $5.9 \pm 0.9$ & $1.5 \pm 0.5$ & $2.0 \pm 0.3$ \\
\hline
\end{tabular}

*Indek stomata $=[$ jumlah stomata/(jumlah stomata + jumlah epidermis $)] \times 100$

Tabel 3. Ukuran stomata sayatan paradermal ke lima kultivar S. trifasciata

\begin{tabular}{|c|c|c|c|c|c|c|}
\hline \multirow[t]{3}{*}{ No } & \multirow[t]{3}{*}{ Kultivar } & \multirow[t]{3}{*}{ Posisi } & \multicolumn{4}{|c|}{ Ukuran stomata $(\mu \mathrm{m})$} \\
\hline & & & \multicolumn{2}{|c|}{ Adaksial } & \multicolumn{2}{|c|}{ Abaksial } \\
\hline & & & Panjang & Lebar & Panjang & Lebar \\
\hline \multirow[t]{4}{*}{1} & $\begin{array}{ll}\text { cv. } & \text { Metalica }\end{array}$ & Pangkal & 41.9 & 24.2 & 40.8 & 25.6 \\
\hline & & Tengah & 41.5 & 26.0 & 43.4 & 29.7 \\
\hline & & Ujung & 41.5 & 28.9 & 41.2 & 29.0 \\
\hline & & Rataan & $41.6 \pm 0.2$ & $26.4 \pm 2.4$ & $41.8 \pm 1.4$ & $28.1 \pm 2.2$ \\
\hline \multirow[t]{4}{*}{2} & cv. Moonsine & Pangkal & 42.2 & 29.9 & 42.1 & 33.3 \\
\hline & & Tengah & 43.1 & 29.3 & 42.7 & 33.0 \\
\hline & & Ujung & 39.8 & 34.0 & 39.6 & 29.9 \\
\hline & & Rataan & $41.7 \pm 1.7$ & $31.1 \pm 2.6$ & $41.5 \pm 1.6$ & $32.1 \pm 1.8$ \\
\hline \multirow[t]{4}{*}{3} & cv. African Dawn & Pangkal & 40.6 & 32.4 & 37.7 & 33.0 \\
\hline & & Tengah & 37.3 & 32.1 & 41.7 & 35.9 \\
\hline & & Ujung & 40.1 & 33.6 & 40.8 & 32.9 \\
\hline & & Rataan & $39.3 \pm 1.7$ & $32.7 \pm 0.8$ & $40.1 \pm 2.1$ & $33.9 \pm 1.7$ \\
\hline \multirow[t]{4}{*}{4} & cv. NN & Pangkal & 42.9 & 35.5 & 40.3 & 35.9 \\
\hline & & Tengah & 40.6 & 36.5 & 42.5 & 38.6 \\
\hline & & Ujung & 43.7 & 35.4 & 42.7 & 36.2 \\
\hline & & Rataan & $42.4 \pm 1.6$ & $35.8 \pm 0.6$ & $41.8 \pm 1.3$ & $36.9 \pm 1.5$ \\
\hline \multirow[t]{4}{*}{5} & cv. Bantel's Sensation & Pangkal & 42.7 & 37.8 & 43.1 & 36.6 \\
\hline & & Tengah & 42.9 & 37.0 & 43.9 & 37.5 \\
\hline & & Ujung & 42.6 & 35.5 & 43.8 & 37.4 \\
\hline & & Rataan & $42.7 \pm 0.2$ & $36.8 \pm 1.2$ & $43.6 \pm 0.4$ & $37.2 \pm 0.5$ \\
\hline
\end{tabular}


beku. Ketebalan masing-masing lapisan penyusun daun tersebut ditunjukkan pada Tabel 4.

Analisis Klorofil. Hasil analisis kandungan klorofil a, klorofil b, dan klorofil total ke lima kultivar S. trifasciata dapat dilihat pada Tabel 5. Kandungan klorofil a pada semua kultivar selalu lebih tinggi dibandingkan kandungan klorofil b.

\section{PEMBAHASAN}

Stomata berfungsi sebagai tempat pertukaran gas pada tanaman. Stomata merupakan modifikasi epidermis berupa pori yang diapit oleh sel penjaga yang dikelilingi oleh beberapa sel tetangga. Berdasarkan pengamatan sayatan paradermal, stomata kelima kultivar $S$. trifasciata dapat

Tabel 4. Ketebalan lapisan penyusun daun berdasarkan sayatan transversal ke lima kultivar S. trifasciata

\begin{tabular}{rrrrrr}
\hline \multirow{2}{*}{$\begin{array}{l}\text { Ketebalan } \\
\mu \mathrm{m})\end{array}$} & \multicolumn{5}{c}{ Kultivar } \\
\cline { 2 - 6 } Kutikula & cv. Metalica & cv. Moonsine & cv. African Dawn & cv. NN & cv. Bantel's sensation \\
Abaksial & $7.7 \pm 0.3$ & $11.3 \pm 0.3$ & $9.2 \pm 1.0$ & $11.2 \pm 0.5$ & $10.2 \pm 0.5$ \\
Adaksial & $8.8 \pm 0.3$ & $20.0 \pm 0.5$ & $12.0 \pm 0.0$ & $12.0 \pm 0.0$ & $12.0 \pm 0.3$ \\
Epidermis & & & & \\
Abaksial & $27.2 \pm 0.6$ & $28.5 \pm 1.0$ & $19.7 \pm 0.6$ & $27.7 \pm 0.3$ & $25.7 \pm 0.3$ \\
Adaksial & $31.0 \pm 0.0$ & $34.2 \pm 0.8$ & $22.2 \pm 0.3$ & $31.2 \pm 0.3$ & $30.7 \pm 4.2$ \\
Mesofil & $1811.7 \pm 8.9$ & $4946.7 \pm 5.7$ & $1626.0 \pm 7.6$ & $1881.7 \pm 2.9$ & $4458.3 \pm 5.7$ \\
Daun & $1945.0 \pm 0.0$ & $5553.3 \pm 7.6$ & $1788.0 \pm 5.0$ & $1980.0 \pm 5.0$ & $4530.0 \pm 9.8$ \\
\hline
\end{tabular}

Tabel 5. Kandungan klorofil a, klorofil b, dan klorofil total pada ke lima kultivar S.trifasciata

\begin{tabular}{lccc}
\hline \multicolumn{1}{c}{ Kultivar } & Klorofil a (mg/g) & Klorofil b (mg/g) & Klorofil Total (mg/g) \\
\hline cv. Metalica & $0.175^{\mathrm{d}}$ & $0.058^{\mathrm{c}}$ & $0.233^{\mathrm{c}}$ \\
cv. Moonsine & $0.225^{\mathrm{bc}}$ & $0.175^{\mathrm{b}}$ & $0.400^{\mathrm{b}}$ \\
cv. African Dawn & $0.433^{\mathrm{a}}$ & $0.275^{\mathrm{a}}$ & $0.708^{\mathrm{a}}$ \\
cv. NN & $0.243 \mathrm{~b}$ & $0.175^{\mathrm{b}}$ & $0.418^{\mathrm{b}}$ \\
cv. Bantel's Sensation & $0.183^{\text {cd }}$ & $0.118^{\mathrm{bc}}$ & $0.300^{\mathrm{c}}$
\end{tabular}

Keterangan: huruf yang berbeda pada kolom yang sama menunjukkan beda nyata pada uji Duncan 1\%
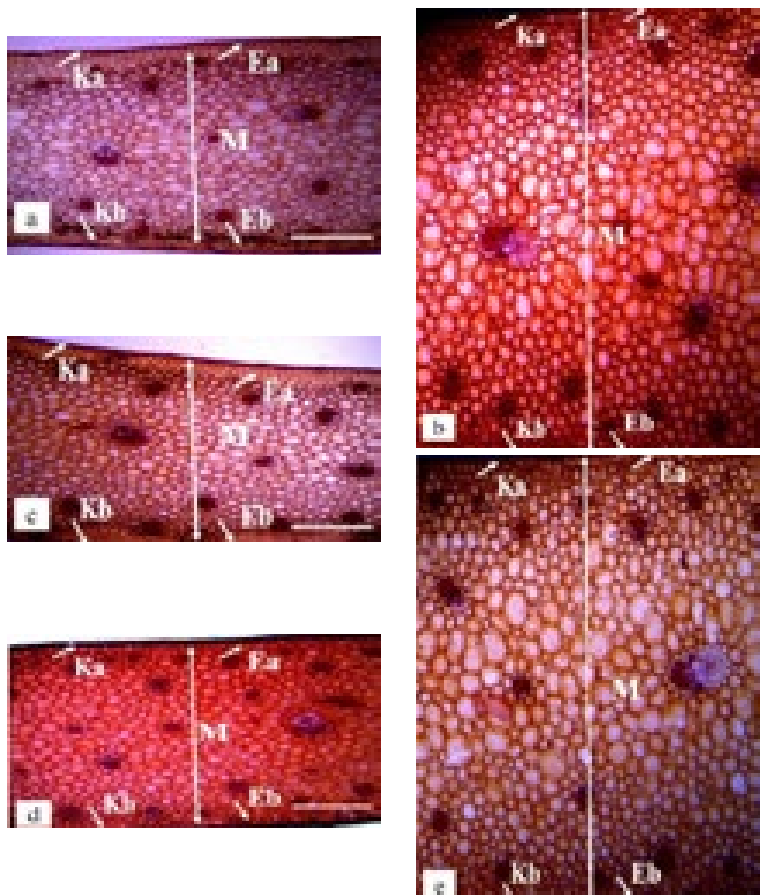

Gambar 5. Sayatan transversal daun ke lima kultivar $S$. trifasciata: (a). cv. Metalica, (b). cv. Moonsine, (c). cv. African Dawn, (d) cv. NN, dan (e). cv. Bantel's Sensation, (Ka) Kutikula adaksial, (Kb) Kutikula abaksial, (Ea) Epidermis adaksial, (Eb) Epidermis abaksial, (M) Mesofil. Garis skala: $700 \mu \mathrm{m}$ dijumpai pada sisi abaksial maupun adaksial daun. Keadaan stomata yang demikian disebut bersifat amfistomatik (Fahn 1990). Kelima kultivar $S$. trifasciata memiliki tipe stomata tetrasitik yang dicirikan dengan empat sel tetangga yang tegak lurus dan sejajar mengelilingi stomata (Stern et al. 1994).

Parameter yang digunakan dalam pengamatan sayatan paradermal meliputi kerapatan stomata, indeks stomata, dan ukuran stomata. Ke lima kultivar $S$. trifasciata memiliki kerapatan stomata pada bagian abaksial daun yang lebih tinggi dibandingkan bagian adaksial daun (Tabel 2). $S$. trifasciata merupakan tanaman yang hidup di darat, jumlah stomata yang rendah dibagian adaksial berguna untuk mengurangi transpirasi. Hal ini sesuai dengan hasil pengamatan Haryanti (2010) yang menganalisis 68 tanaman Dikotil dan 32 tanaman Monokotil dan mendapatkan hanya 4 spesies yang memiliki jumlah stomata lebih banyak pada bagian adaksial.

Semakin tinggi kerapatan stomata suatu tanaman, semakin tinggi pula kemampuan tanaman tersebut menyerap logam berat atau partikel di udara, seperti ditunjukan Fakuara (1996) pada Felicium decipiens, Pithecelobium dulce, dan Michellia champaca. Diantara kelima kultivar S. trifasciata, cv. Moonsine memiliki KS yang paling tinggi. Hal ini didukung oleh adanya sebaran stomata yang berkelompok pada kultivar ini. 
Stomata berfungsi sebagai tempat utama bagi polutan untuk melakukan penetrasi terhadap tanaman (Dickison 2000). Nilai KS dan IS tertinggi dijumpai pada cv. Moonsine (Tabel 2). Kerapatan dan indeks stomata suatu tanaman dapat digunakan sebagai bioindikator dan biomonitoring kualitas udara. Semakin tinggi KS dan IS, maka semakin baik pula tanaman dalam penyerapan polusi udara (Balasooriya et al. 2008). Oleh karena itu, S. trifasciata cv. Moonsine diduga memiliki kemampuan yang baik dalam penyerapan polusi udara dibandingkan kultivar lainnya.

Pada penelitian menggunakan 25 pohon Leguminosae Agustini et al. (1999) membagi stomata berdasarkan ukuran panjang stomata yang terdiri dari kurang panjang $(<20 \mu \mathrm{m})$, panjang $(20-25 \mu \mathrm{m})$, dan sangat panjang $(>25$ $\mu \mathrm{m})$. Berdasarkan hasil pengamatan stomata ke lima kultivar $S$. trifasciata termasuk kategori sangat panjang (Tabel 3). ). Ukuran panjang stomata yang tinggi ini sangat membantu dalam penyerapan gas polutan dan juga $\mathrm{CO}_{2}$ untuk fotosintesis. Ukuran panjang stomata yang meningkat merupakan indikasi adaptasi tanaman terhadap pencemar udara. Tanaman yang tumbuh di lingkungan terpolusi cenderung akan mempertahankan dirinya dengan meningkatkan ukuran stomata (Muud dan Kozlowski 1975)

Hasil pengamatan sayatan transversal menunjukkan bahwa daun $S$. trifasciata tersusun atas beberapa lapisan yakni kutikula (atas dan bawah), epidermis (atas dan bawah) serta jaringan mesofil. S. trifasciata memiliki jaringan mesofil yang terdiri atas jaringan parenkim dengan struktur yang sama (Gambar 5) dan tidak berupa jaringan palisade atau jaringan bunga karang,

Kutikula merupakan pertahanan pertama daun terhadap bahan-bahan pencemar yang masuk melalui daun karena letaknya yang berada paling luar dari lapisan epidermis. Modifikasi pada tebal kutikula merupakan respon untuk mengurangi transpirasi dan reaksi tanaman terhadap masuknya bahan pencemar. Senyawa pencemar udara dapat meningkatkan tebal kutikula pada Glycine max sebagai bentuk pertahanannya (Weryszko dan Hwil 2005). Diantara kelima kultivar tersebut, cv. Moonsine memiliki lapisan kutikula sisi adaksial dan abaksial yang paling tebal dibandingkan dengan kultivar lainnya.

Epidermis berfungsi untuk melindungi jaringan dalam tumbuhan. Epidermis pada kelima kultivar S. trifasciata tersusun atas satu lapis sel. Ke lima kultivar S. trifasciata memiliki epidermis bagian adaksial yang lebih tebal dibandingkan bagian abaksial. Sedang ditinjau dari segi kultivar cv. Moonsine memiliki lapisan epidermis yang lebih tebal dibandingkan kultivar lainnya (Tabel 4).

Mesofil merupakan tempat terjadinya proses fotosintesis karena sel-sel di jaringan ini banyak mengandung klorofil. Tebal mesofil ke lima kultivar S. trifasciata berkorelasi dengan tebalnya daun, semakin tebal daun maka semakin tebal mesofil (Tabel 4). Dalam usaha untuk mempertahankan diri dapat terjadi penurunan ukuran lapisan mesofil pada tanaman yang ditanam pada daerah yang tercemar dibandingkan daerah yang tidak tercemar (Stevovic et al. 2010).

Ketebalan daun kelima S. trifasciata yang diteliti memiliki variasi dari $1788 \mu \mathrm{m}$ - $5553 \mu \mathrm{m}$ (Tabel 4). Daun yang tipis akan menyebabkan gas pencemar lebih mudah terserap. Kultivar cv. African Dawn memiliki ketebalan daun yang paling tipis dibandingkan kultivar lainnya. Semakin tebal daun maka penyerapan gas akan semakin rendah. Hal ini terkait dengan kesulitan gas pencemar menembus jaringan daun yang tebal sehingga gas yang terserap daun relatif kecil (Patra 2002).

Analisis klorofil. Klorofil merupakan pigmen hijau yang berfungsi sebagai penyerap cahaya dalam kegiatan fotosintesis yang dibutuhkan dalam pertumbuhan dan perkembangan tanaman. Kandungan klorofil a, klorofil b dan total klorofil S. trifasciata (Tabel 5) menunjukkan ada beda nyata antar kultivar. S. trifasciata cv. African Dawn memiliki nilai kandungan klorofil tertinggi.

Kadar klorofil dapat digunakan sebagai indikator penyerap polusi udara pada tanaman yang sensitif. Reduksi kandungan klorofil biasa dijumpai pada tanaman yang terkena cekaman polusi lingkungan (Solichatun dan Anggarwulan 2007; ELSadek et al. 2012). Ficus yang tumbuh di-daerah industrial memiliki kandungan klorofil yang lebih rendah dibandingkan yang tumbuh di daerah rural atau hutan (Kapoor 2014). Degradasi pigmen klorofil ini dapat disebabkan oleh aksi phytotoxin SO2. Gejala kerusakan yang ditimbulkan berawal dari tingkat biokimia, diikuti dengan tingkat ultrastruktural dan tingkat sel (rusaknya dinding sel dan pecahnya inti sel) yang diakhiri dengan terlihatnya gejala klorosis dan nekrosis pada jaringan daun.

Kadar klorofil pada daun Pterocarpus indicus dan Swietenia mahagoni menurun dengan meningkatnya kadar partikel pencemaran udara (Karliansyah 1999). $S$. trifasciata cv African Dawn memiliki nilai kandungan klorofil tertinggi - sehingga dianggap memiliki modal dasar yang lebih baik dalam mempertahankan diri dalam lingkungan yang berpolusi dibandingkan keempat kultivar lainnya.

\section{DAFTAR PUSTAKA}

Agustini, Nurisjah S, Sulistyaningsih YC. 1999. Identifikasi ciri arsitekturis dan kerapatan stomata 25 jenis pohon suku Leguminosae untuk elemen lanskap tepi jalan. Bul. Taman Lansk Indones 2(1): 2-6.

Arnon DI. 1949. Cooper enzymes in isolated chloroplast, polyphenol oxidase in Beta vulgaris. Plant Physiol. 24(1): $1-15$.

Backer CA, Bakhuizen VDB. 1963. Flora of Java Volume III. Groningen (DC) : NV. P. Nhordhoof Groningen.

Balasooriya BLWK, Samson R, Mbikwa F, Vitharana UWA, Boeckx P. 2008. Biomonitoring of urban habitat quality by anatomical and chemical leaf characteristics. Environ. Exp. Bot. 65(2): 386-394.

Dickison WC. 2000. Integrative Plant Anatomy. New York (USA): John Wiley \& Sons.

ELSadek M, Koriesh E, Fujii E, Moghazy E, and Abd El Fatah Y. 2012. Correlation between some components of interior plants and their efficiency to reduce Formaldehyde, Nitrogen and Sulfur Oxides from indoor air. Int. Res. J. Plant Sci. 3(10): 222-229. 
Fahn A. 1990. Plant Anatomy 4th Ed. New York (US): Pergamon Pr.

Fakuara Y. 1996. Studi toleransi tanaman peneduh jalan kemampuan dalam mengurangi polusi udara. J Penel Kar. Univ. Trisakti 2 (7): 70-79.

Gardner FP, Pearce RB, Mitchell RL. 1991. Fisiologi Tanaman Budidaya. Susilo H, penerjemah. Jakarta (ID): UI Pr Terjemahan dari: Crop Physiology.

Haryanti S. 2010. Jumlah dan distribusi stomata pada daun beberapa spesies tanaman dikotil dan monokotil. Bul. Anat. Fis 18(2): 1-8.

Kapoor CS. 2014. Ficus benghalensis L. Tree as an efficient option for controlling air pollution. Res. Health Nutr (RHN) J 2: 49-59.

Karliansyah NSW. 1999. Klorofil daun Angsana dan Mahoni sebagai bioindikator pencemaran udara. J Lingk. Pemb. 19(4): 290-305.

Muud JB, Kozlowski TT. 1975. Responses of Plants to Air Pollution. London (UK): Academic Pr.

Patra AD. 2002. Faktor tanaman dan faktor lingkungan yang mempengaruhi kemampuan tanaman dalam menyerap polutan gas $\mathrm{NO}_{2}$. [tesis]. Bogor (ID): Institut Pertanian Bogor.

Purwanto AW. 2006. Sansevieria Flora Cantik Penyerap Racun Yogyakarta (ID): Kanisius.
Sass JE. 1951. Botanical Microtechnique. Iowa (US): The Iowa State College Pr.

Smith WH. 1981. Air Pollution and Forest: Interaction Between Air Contaminants and Forest Ecosystems. New York (US): Springer-Verlag.

Solichatun, Anggarwulan E. 2007. Kajian klorofil dan karotenoid Plantago major L. dan Phaseolus vulgaris L. sebagai bioindikator kualitas udara. J Biodivers. 8(4): 279-282.

Starkman ES. 1969. Combustion Generated Air Polution. New York (US): Plenum Pr.

Stern WL, Morris, Judd WS. 1994. Anatomy of the thick leaves in Dendrobium section rhizobium (Orchidaceae). Int. J. Plant Sci. 155(6): 716-729.

Stevovic S, Mikovilovic VS, Dragosavac DC. 2010. Environmental impact on morphological and anatomical structure of Tansy. Afric. J. Biotech 9(16): 2413-2421.

Stover H. 1983. The Sansevieria Book. California (US): Endangered Species Pr.

Treshow M, Anderson FK. 1989. Plant Stress from Air Pollution. New York (USA): Ltd. Chichester.

Weryszko CE, Hwil M. 2005. Lead induced histological and ultrastructural changes in the leaves of soybean [Glycine max (L) Merr]. Soil Sci. Plant Nutr 51: $203-212$.

Wilmer CM. 1983. Stomata. London (UK): Longman Group Ltd 